\title{
Concomitant Use of Direct Oral Anticoagulants and Antiepileptic Drugs: A Prospective Cohort Study in Patients with Atrial Fibrillation
}

\author{
Michela Giustozzi ${ }^{1}$ (D) Matteo Mazzetti ${ }^{2} \cdot$ Maurizio Paciaroni $^{1} \cdot$ Giancarlo Agnelli $^{1} \cdot$ Cecilia Becattini $^{1}$. \\ Maria Cristina Vedovati ${ }^{1}$
}

Accepted: 24 October 2020 / Published online: 7 December 2020

(c) The Author(s) 2020

\begin{abstract}
Background European guidelines do not recommend the use of carbamazepine, levetiracetam, phenobarbital, phenytoin, topiramate and valproic acid in patients taking direct oral anticoagulants (DOACs). Little is known regarding the clinical relevance of the interaction between DOACs and antiepileptic drugs.

Objectives To evaluate the incidence of thromboembolic and bleeding events in patients with non-valvular atrial fibrillation (AF) concurrently treated with DOACs and antiepileptic drugs.

Methods This is a prospective multicentre cohort study of patients with non-valvular AF concurrently treated with DOACs and antiepileptic drugs. The primary outcome was ischaemic stroke/transient ischaemic attack (TIA)/systemic embolism (SE). Secondary outcome was major bleeding (MB). Incidence rates (\% patient-year) were evaluated for the study outcomes. Results Overall, 91 patients were included. Mean age was $78 \pm 9.5$ years, $49.5 \%$ were female. $\mathrm{Mean}_{\mathrm{CHA}} \mathrm{DS}_{2}$-VASc score was $4.76 \pm 1.59$ and mean HAS-BLED was $2.67 \pm 1.26$. Overall, $41,20,11,10$ and 9 out of 91 patients were treated with levetiracetam, valproic acid, phenobarbital, carbamazepine and other antiepileptic drugs, respectively. During a median follow-up of $17.5 \pm 14.5$ months, stroke/TIA/SE occurred in 9 patients (5.7\% patient-year) and MB in 3 patients (1.9\% patientyear). Ischaemic stroke was fatal in 3 patients (1.9\% patient-year) and MB in one patient ( $0.6 \%$ patient-year).

Conclusion In this cohort, patients with non-valvular AF treated with DOACs and antiepileptic drugs appear to have a relatively high rate of thromboembolic events.
\end{abstract}

\section{Introduction}

Direct oral anticoagulants (DOAC) are increasingly replacing vitamin $\mathrm{K}$ antagonists (VKA) for the prevention of stroke in atrial fibrillation (AF) and for the treatment of venous thromboembolism. In randomised clinical trials in these clinical settings, DOACs were shown to be non-inferior compared to VKAs concerning efficacy, with the advantage of a reduction in major bleeding [1,2]. In addition, the use of DOACs in fixed doses without laboratory monitoring has led to an awaited improved practicality. Based on all these issues, current international guidelines recommend DOACs

Michela Giustozzi

michelagiustozzi@hotmail.it; michela.giustozzi@unipg.it

1 Internal Vascular and Emergency Medicine and Stroke Unit, University of Perugia, Perugia, Italy

2 Internal Medicine of Montevarchi, University of Florence, Florence, Italy

\section{Key Points}

The risk of epilepsy is double in patients with atrial fibrillation (AF), possibly linked to silent stroke. Thus, a high proportion of patients with $\mathrm{AF}$ require the concomitant long-term administration of oral anticoagulation and antiepileptic therapy. Little is known about clinical interactions between antiepileptics (AEDs) and direct anticoagulants (DOACs).

In this prospective study, we found that patients with non-valvular AF treated with DOACs and antiepileptic drugs appear to have a relatively high rate of thromboembolic events.

Our findings suggest that the interaction between AEDs and DOACs might be of high clinical relevance. Indeed, caution is needed when prescribing AEDs to patients on concomitant treatment with DOACs. 
as anticoagulants of choice for patients with non-valvular $\mathrm{AF}[3]$.

DOACs have different pharmacokinetic profiles [4]. Direct factor Xa inhibitors such as apixaban, edoxaban and rivaroxaban are substrates of the cytochrome P450 (CYP) system, and especially the CYP3A4 isoform, while dabigatran is not substrate of cytochrome P450 system [4]. Their intestinal absorption and renal elimination are dependent on the permeability of glycoprotein (P-gp) efflux transporter protein system. Thus, concomitant treatment with drugs that influence the P-gp or CYP3A4 system might increase or decrease serum DOAC levels. Antiepileptic drugs (AEDs) seem to affect the P-gp and the CYP3A4 system [5, 6]. However, AEDs differ from each other in terms of mechanism and drug-drug interaction. While phenobarbital, phenytoin, carbamazepine, oxcarbazepine are established inducers of P-gp and the CYP3A4 systems, the pharmacokinetic properties of valproic acid and levetiracetam are still controversial [5-8].

Risk of epilepsy in patients with AF appears to be double compared to patients without AF [9]. Moreover, post-stroke epilepsy accounts for $30-40 \%$ of all cases of epilepsy in the elderly and it is a serious condition with increased mortality and reduced function outcome [10]. Thus, a high proportion of patients with AF require the long-term concomitant administration of oral anticoagulation and antiepileptic therapy.

To date, data on potential interactions between DOACs and AEDs are limited. The European Heart Rhythm recommendations do not support the use of commonly used AEDs (e.g. carbamazepine, levetiracetam, phenobarbital, phenytoin, topiramate and valproic acid) in patients concurrently taking DOACs [11]. These recommendations are based on expert opinions, DOAC summary of product characteristics and on animal or in vitro studies.

The aim of this study was to evaluate the incidence of thromboembolic and bleeding events in a cohort of patients with non-valvular AF concurrently treated with AEDs and DOACs.

\section{Methods}

\subsection{Patients}

Consecutive patients with non-valvular AF treated with DOACs were prospectively included in on-going prospective cohorts [12]. Data from patients treated with both DOACs and AEDs from the two cohorts were extrapolated and merged in a collaborative database and study. Patients were enrolled at the Internal, Vascular and Emergency MedicineStroke Unit in Perugia and at the Anticoagulation Clinic in
Arezzo from 2014 to December 2018 [12]. These patients were prospectively observed until January 2020. Decisions concerning the choice of DOAC and AED for each individual patient were taken by the attending physician. In both cohorts, adherence to the criteria of the European Medicines Agency (EMA) for prescription of reduced doses of DOACs was suggested. Exclusion criteria were refusal of informed consent or treatment with anticoagulant agents other than DOACs. The study was approved by the Ethical Committee and/or Institutional Review Boards of the participating centres.

\subsection{Data Collection}

For each patient, the following data were collected: age, sex, comorbidities (hypertension, congestive heart failure, diabetes, previous stroke, vascular diseases, previous bleeding), previous vitamin-K antagonists use, type of AF (first diagnosed, paroxysmal and permanent AF), laboratory tests (e.g. creatinine clearance, eGFR according to CockroftGault formula), type and dosage of DOAC, type of AEDs. Risks of stroke or bleeding were defined according to the $\mathrm{CHA}_{2} \mathrm{DS}_{2}$-VASc and HAS-BLED score [13, 14].

Patients' observation started at the time of DOAC prescription and ended in case of death or permanent DOAC or AED discontinuation. Follow-up visits or telephone contacts were scheduled every 6 months or in case of signs/symptoms of study outcome events.

\subsection{Study Outcome Events}

The primary effectiveness outcome was the composite of ischaemic stroke, transient ischaemic attack (TIA) and systemic embolism (SE). The primary safety outcome was major bleeding (MB). Secondary outcomes of the study were (i) overall mortality and (ii) clinically relevant bleedings (CRB).

Stroke was defined as a focal neurological defect, lasting at least $24 \mathrm{~h}$ while TIA as a transient episode of neurological dysfunction resulting from focal cerebral ischaemia not associated with permanent cerebral infarction. Bleeding was defined as a major event according to the International Society on Thrombosis and Haemostasis (ISTH) definition, if clinically overt and associated with a decrease in the haemoglobin level of $2.0 \mathrm{~g}$ per decilitre or more, transfusion of 2 or more units of red cells, if it was intracranial or retroperitoneal, if it occurred in another critical site, or contributed to death [15]. CRB were the composite of major bleeding and clinically relevant non-major bleeding. Clinically relevant non-major bleeding was defined according to the ISTH criteria as overt bleeding that did not meet the criteria for major bleeding but was associated with medical intervention, unscheduled contact with a physician, interruption or 
discontinuation of DOAC [15]. In case of death, the presumed cause was reported as adjudicated by the attending physician. The results of all the available tests used to confirm/exclude bleeding or thromboembolism as the cause of death were reported. Permanent discontinuation was defined as drug withdrawal for a period longer than 30 days.

\subsection{Statistical Analysis}

Categorical data were reported as frequencies and continuous data as mean \pm SD or median (range). Study outcome events were presented as number of events per 100 personyears. We performed Kaplan-Meier survival analysis to estimate the time course of stroke/TIA/SE and of MB in the overall population and according to the type of AEDs: enzyme-inducing AEDs (phenytoin, phenobarbital, carbamazepine, oxcarbazepine) versus other AEDs.

Cox regression analysis was used to identify predictors of stroke/TIA/SE and of MB. The predictors included in the analysis were: age, sex, previous stroke or TIA, reduced dose of DOAC, previous use of VKA, $\mathrm{CHA}_{2} \mathrm{DS}_{2}$-VASc and HAS-BLED score. Results were reported as hazard ratio (HRs) with $95 \%$ confidence intervals (CIs). $P$-values $\leq 0.05$ were considered statistically significant. Data were analysed with the SPSS/PC Win package 22.0.

\section{Results}

Of 2301 patients included in the two cohorts, 91 (3.9\%) patients who were receiving DOACs in combination with antiepileptics were identified and included in this analysis. Mean age was $78 \pm 9.5$ years, $45(49.5 \%)$ patients were female and $44(48 \%)$ had a previous stroke or TIA. Main clinical features of study patients are reported in Table 1. Overall, 15 (16.5\%), 25 (27.5\%), 42 (46.2\%) and 9 (9.9\%) patients were treated with dabigatran, rivaroxaban, apixaban and edoxaban, respectively. Reduced doses of DOAC were prescribed in $34(37.4 \%)$ patients. Before starting DOACs, 20 (22\%) patients were on treatment with VKAs. Among study patients, 41 (45\%) were on treatment with levetiracetam, 20 (22\%) with valproic acid, $11(12 \%)$ with phenobarbital, $10(11 \%)$ with carbamazepine and 9 patients (10\%) with other AEDs (Table 2). Accordingly, 24 (26\%) patients were on treatment with enzyme-inducing AEDs and 67 (74\%) patients with other AEDs.

\subsection{Study Outcome Events}

Median follow-up was $17.5 \pm 14.5$ months.

During the study period, ischaemic stroke/TIA/SE occurred in 9 patients (5.7\% patient-year). Of them, 8 patients had ischaemic stroke and 1 patient had a TIA (Fig. 1, Table 2).
Ischaemic stroke was fatal in 3 patients (1.9\% patientyear). The main characteristics of thromboembolic events are reported in Table 3. All patients who experienced a thromboembolic event were aged $\geq 75$ years, $6(67 \%)$ had a $\mathrm{CHA}_{2} \mathrm{DS}_{2}$-VASc score $>3$ and a history of stroke. One patient who died from ischaemic stroke was on concomitant treatment with phenobarbital and levetiracetam. No differences were observed in terms of risk of ischaemic stroke/TIA/SE between patients treated with enzyme-inducing AEDs and patients treated with other AEDs (log-rank=0.342).

MB occurred in 3 patients (1.9\% patient-year), one of whom had fatal genito-urinary bleeding $(0.6 \%$ patient-year) (Fig. 2, Table 2). In each patient who experienced a study outcome event, the DOAC dose was the one recommended according to EMA criteria.

Seven patients had CRB (4.5\% patient-years). All-cause death occurred in 14 patients (8.7\% patient-year). During the study period, 3 patients permanently discontinued anticoagulant treatment (1.9\% patient-year). Reasons for discontinuation were starting of anti-hepatitis C therapy in one patient and progressive failure of renal function and TIA in the other.

\subsection{Predictors of Primary Outcomes}

At univariable analysis, increasing age was significantly associated with an increased risk of stroke/TIA/SE (HR 1.1, $95 \%$ CI $1.0-1.2, p=0.04)$. The only predictor of MB was the HAS-BLED score (HR 4.5 for each point increase, 95\% CI $1.0-20.5, p=0.04)$. No association was observed between stroke/TIA/SE or MB and the other tested predictors.

\section{Discussion}

In this prospective cohort of patients with non-valvular AF treated with DOACs and AEDs and followed for nearly 1.5 years, we observed a relatively high rate of ischaemic stroke/SE (5.6\% patient-year) and a rate of MB of $1.9 \%$ patient-year.

To date, little is known about the potential interaction between DOACs and AEDs since data are mainly available from animal or in vitro studies and there are only a few case reports and one retrospective study in humans [16-23]. To the best of our knowledge, this is the first study reporting on the incidence of ischaemic stroke/TIA/SE in a cohort of AF patients treated with DOACs and AEDs. Although a formal comparison cannot be performed, we found an overall rate of thromboembolic events of 5.7\% patient-year, which was higher than rates observed in the main post-marketing cohort studies of patients with AF treated with DOACs [24-26]. These could partly be explained by the different 
Table 1 Main baseline clinical features

\begin{tabular}{|c|c|c|c|c|c|c|}
\hline Variable & Patients $(n=91)$ & Levetiracetam $(n=41)$ & Valproic acid $(n=20)$ & Phenobarbital $(n=11)$ & $\begin{array}{l}\text { Carbamaze- } \\
\text { pine }(n=10)\end{array}$ & Other drugs ${ }^{\mathrm{a}}(9)$ \\
\hline Age years, mean $\pm S D$ & $78.29 \pm 9.5$ & $77.95 \pm 9.5$ & $74.29 \pm 9.5$ & $85.91 \pm 5.5$ & $80.60 \pm 4.7$ & $79.63 \pm 13.9$ \\
\hline Age > 75 years, $n(\%)$ & $72(79)$ & $31(76)$ & $13(65)$ & $10(91)$ & $10(100)$ & $8(89)$ \\
\hline Female, $n(\%)$ & $45(50)$ & $17(41)$ & $14(70)$ & $5(45)$ & $5(50)$ & $4(44)$ \\
\hline Previous stroke/TIA, $n(\%)$ & $44(48)$ & $22(54)$ & $8(40)$ & $6(55)$ & $3(30)$ & $5(55)$ \\
\hline \multicolumn{7}{|l|}{ Type of DOAC, } \\
\hline Dabigatran, $n(\%)$ & $15(17)$ & $8(19)$ & $5(25)$ & $0(0)$ & $2(20)$ & $0(0)$ \\
\hline Rivaroxaban, $n(\%)$ & $25(27)$ & $8(19)$ & $6(30)$ & $6(55)$ & $4(40)$ & $1(11)$ \\
\hline Apixaban, $n(\%)$ & $42(46)$ & $23(56)$ & $6(30)$ & $3(27)$ & $3(30)$ & $7(77)$ \\
\hline Edoxaban, $n(\%)$ & $9(10)$ & $2(5)$ & $3(15)$ & $2(18)$ & $1(10)$ & $1(11)$ \\
\hline $\begin{array}{l}\text { Reduced dose DOAC, } \\
n(\%)\end{array}$ & $34(37)$ & $12(29)$ & $10(50)$ & $6(55)$ & $5(50)$ & $1(11)$ \\
\hline \multicolumn{7}{|l|}{ Type of AF, } \\
\hline First diagnosis, $n(\%)$ & $9(10)$ & $2(5)$ & $4(20)$ & $1(9)$ & $0(0)$ & $2(22)$ \\
\hline Paroxysmal, $n(\%)$ & $22(24)$ & $9(22)$ & $9(45)$ & $1(9)$ & $2(20)$ & $1(11)$ \\
\hline Permanent, $n(\%)$ & $60(66)$ & $30(73)$ & $7(35)$ & $9(82)$ & $8(80)$ & $6(66)$ \\
\hline Hypertension, $n(\%)$ & $75(82)$ & $33(80)$ & $17(85)$ & $10(91)$ & $7(70)$ & $8(89)$ \\
\hline $\begin{array}{l}\text { Chronic heart failure, } n \\
(\%)\end{array}$ & $31(34)$ & $15(37)$ & $5(25)$ & $4(36)$ & $6(60)$ & $1(11)$ \\
\hline Diabetes mellitus, $n(\%)$ & $19(21)$ & $9(22)$ & $4(20)$ & $2(18)$ & $1(10)$ & $3(33)$ \\
\hline Vascular disease, $n(\%)$ & $18(20)$ & $5(12)$ & $5(25)$ & $3(27)$ & $1(10)$ & $4(40)$ \\
\hline Previous bleeding, $n(\%)$ & $31(34)$ & $12(29)$ & $9(45)$ & $2(18)$ & $5(50)$ & $3(33)$ \\
\hline $\begin{array}{l}\text { Creatinine value, } \\
\text { mean } \pm \mathrm{SD}\end{array}$ & $0.97 \pm 0.3$ & $1.03 \pm 0.3$ & $0.85 \pm 0.26$ & $0.92 \pm 0.33$ & $0.92 \pm 0.32$ & $1.04 \pm 0.28$ \\
\hline $\begin{array}{l}\text { eGFR } \mathrm{mL} / \text { min, mean } \pm \mathrm{SD} \\
\text { Range }\end{array}$ & $\begin{array}{l}69.0 \pm 21.9 \\
36-126\end{array}$ & $63.8 \pm 15.4$ & $80.1 \pm 22.8$ & $61.7 \pm 29.7$ & $71.6 \pm 30.4$ & $61.0 \pm 14.2$ \\
\hline $\begin{array}{l}\mathrm{CHA}_{2} \mathrm{DS}_{2} \text {-VASc score } \\
\text { mean } \pm \mathrm{SD}\end{array}$ & $4.76 \pm 1.59$ & $4.63 \pm 1.46$ & $4.60 \pm 1.72$ & $5.18 \pm 1.77$ & $4.76 \pm 1.59$ & $5.38 \pm 1.50$ \\
\hline Range & $2-9$ & & & & & \\
\hline $\begin{array}{l}\mathrm{CHA}_{2} \mathrm{DS}_{2}-\mathrm{VASc}=0-1, \\
n(\%)\end{array}$ & $1(1)$ & 0 & 1 & 0 & 0 & 0 \\
\hline $\begin{array}{l}\mathrm{CHA}_{2} \mathrm{DS}_{2}-\mathrm{VASc}=2-3, \\
\quad n(\%)\end{array}$ & $19(21)$ & 10 & 3 & 2 & 2 & 2 \\
\hline $\begin{array}{l}\mathrm{CHA}_{2} \mathrm{DS}_{2}-\mathrm{VASc}=4, \\
\quad n(\%)\end{array}$ & $18(20)$ & 7 & 7 & 1 & 3 & 0 \\
\hline $\begin{array}{l}\mathrm{CHA}_{2} \mathrm{DS}_{2}-\mathrm{VASc}=5, \\
\quad n(\%)\end{array}$ & $23(25)$ & 12 & 3 & 4 & 2 & 2 \\
\hline $\begin{array}{l}\mathrm{CHA}_{2} \mathrm{DS}_{2}-\mathrm{VASc}=6-9, \\
\quad n(\%)\end{array}$ & $30(33)$ & 12 & 5 & 4 & 3 & 5 \\
\hline $\begin{array}{l}\text { HAS-BLED score, } \\
\text { mean } \pm \text { SD }\end{array}$ & $2.67 \pm 1.26$ & $2.67 \pm 1.26$ & $2.30 \pm 1.17$ & $3.18 \pm 1.32$ & $2.67 \pm 1.26$ & $2.88 \pm 1.24$ \\
\hline Range & $1-7$ & & & & & \\
\hline HAS-BLED $=0, n(\%)$ & $2(2)$ & 0 & 1 & 0 & 0 & 1 \\
\hline HAS-BLED $=1, n(\%)$ & $17(19)$ & 9 & 5 & 1 & 2 & 0 \\
\hline HAS-BLED $=2, n(\%)$ & $20(22)$ & 8 & 4 & 3 & 5 & 0 \\
\hline HAS-BLED = $3, n(\%)$ & $30(33)$ & 14 & 7 & 2 & 1 & 6 \\
\hline HAS-BLED $=4-7, n(\%)$ & $22(24)$ & 10 & 3 & 5 & 2 & 2 \\
\hline Previous VKA use, n (\%) & $20(22)$ & $8(19)$ & $4(20)$ & $4(36)$ & $1(10)$ & $3(33)$ \\
\hline $\begin{array}{l}\text { Concomitant use of aspirin } \\
\text { or NSAID, } \mathrm{n}(\%)\end{array}$ & $13(14)$ & $5(12)$ & $4(20)$ & $3(27)$ & $0(0)$ & $1(11)$ \\
\hline $\begin{array}{l}\mathrm{BMI} \mathrm{kg} / \mathrm{m}^{2}, \text { mean } \pm \mathrm{SD} \\
\text { Range }\end{array}$ & $\begin{array}{l}25.14 \pm 4.3 \\
15-44\end{array}$ & $24.86 \pm 3.1$ & $25.39 \pm 6.4$ & $23.55 \pm 2.9$ & $26.30 \pm 6.3$ & $26.8 \pm 2.1$ \\
\hline
\end{tabular}

$A F$ atrial fibrillation, $D O A C$ direct oral anticoagulant; $e G F R$ estimated glomerular filtration rate; NSAID non-steroidal anti-inflammatory drug, TIA transient ischaemic attack, VKA vitamin $\mathrm{K}$-antagonist

${ }^{a}$ Patients treated with: oxcarbazepine $=2 ;$ pregabalin $=2 ;$ phenytoin $=1 ;$ gabapentin $=1 ;$ lacosamide $=1 ;$ lamotrigine $=1 ;$ topiramate $=1$ 
Table 2 Comparison of the main clinical features of our study with post-marketing atrial fibrillation studies

\begin{tabular}{|c|c|c|c|c|}
\hline Variable & Present study & $\begin{array}{l}\text { GLORIA } \\
\text { AF [24] }\end{array}$ & $\begin{array}{l}\text { ORBIT } \\
\text { AF [25] }\end{array}$ & $\begin{array}{l}\text { GAR- } \\
\text { FIELD } \\
\text { AF [26] }\end{array}$ \\
\hline Age years, mean & 78 & 70 & 75 & 71 \\
\hline Age $>75$ years, $\%$ & 79 & 37 & NR & 37 \\
\hline Female, $\%$ & 50 & 45 & 42 & 44 \\
\hline $\begin{array}{l}\text { Previous stroke/ } \\
\text { TIA, \% }\end{array}$ & 48 & 10 & 19 & 11 \\
\hline Hypertension, \% & 82 & 79 & 86 & 76 \\
\hline Heart failure, $\%$ & 34 & 25 & 40 & 23 \\
\hline $\begin{array}{l}\text { Diabetes melli- } \\
\text { tus, \% }\end{array}$ & 21 & 23 & 34 & 22 \\
\hline $\begin{array}{l}\mathrm{CHADS}_{2},-\mathrm{VASc} \\
\text { mean }\end{array}$ & 4.76 & 3.2 & $4^{\mathrm{a}}$ & $3.0^{\mathrm{a}}$ \\
\hline $\begin{array}{l}\text { Mean follow-up } \\
\text { (years) }\end{array}$ & 1.8 & 2.0 & 2.0 & 1.0 \\
\hline $\begin{array}{l}\text { Ischaemic stroke/SE/ } \\
\text { pts-y }\end{array}$ & 5.7 & 0.7 & 1.3 & 1.3 \\
\hline $\begin{array}{l}\text { Major bleeding, } \\
\text { pts-y }\end{array}$ & 1.9 & 1.1 & 4.1 & 0.8 \\
\hline
\end{tabular}

$N R$ not reported, $S E$ systemic embolism, TIA transient ischaemic attack

${ }^{\text {a Median }}$

patient profile. Indeed, our patients were older, had a higher thromboembolic risk score and a higher rate of history of stroke compared to patients included in the main AF postmarketing cohort studies.
It is well known that the potential interaction between DOACs and AEDs is based on the P-gp and CYP3A4 systems [4]. However, AEDs differ from each other in important pharmacokinetic characteristics and potential drug-drug interaction. In fact, phenobarbital, phenytoin, carbamazepine and oxcarbazepine are established inducers of both metabolic enzymes such as CYP3A4 and/or P-glycoprotein [7, 8]. In contrast, other AEDs such as valproic acid and levetiracetam have pharmacokinetic properties that are still questionable and studies documenting their effects on the concentrations of CYP3A and/or P-gp substrates are few and controversial [4]. Potential drug-drug interactions still remain unknown in other AEDs such as pregabalin, gabapentin, lamotrigine, lacosamide [4].

Carbamazepine is a strong inducer of CYP3A4 and P-gp transporter and can cause a marked reduction of DOAC in the plasma concentrations by $80 \%$ or more in humans [16-18]. In animal studies, induction of P-gp was found by levetiracetam, phenobarbital and phenytoin [19, 20]. However, the clinical data show that levetiracetam is not a $\mathrm{P}$-gp inducer [27]. In contrast, in a recent case report, levetiracetam seems to reduce rivaroxaban plasma levels acting as P-gp inducer [28]. No effect was observed for levetiracetam and CYP3A4 activity in vitro [21]. In in vitro studies, valproic acid increased $\mathrm{P}-\mathrm{gp}$ activities while controversial results have been reported for its potential interactions with CYP3A4 system [6, 22, 23].

Whether these potential interactions may have a clinically relevant significance is largely unknown. In a recent analysis of adverse event reports submitted to Food and Drug
Fig. 1 Risk and incidence rates of ischaemic stroke/TIA/SE. $p t s-y$ patient-year, $S E$ systemic embolism, TIA transient ischaemic attack

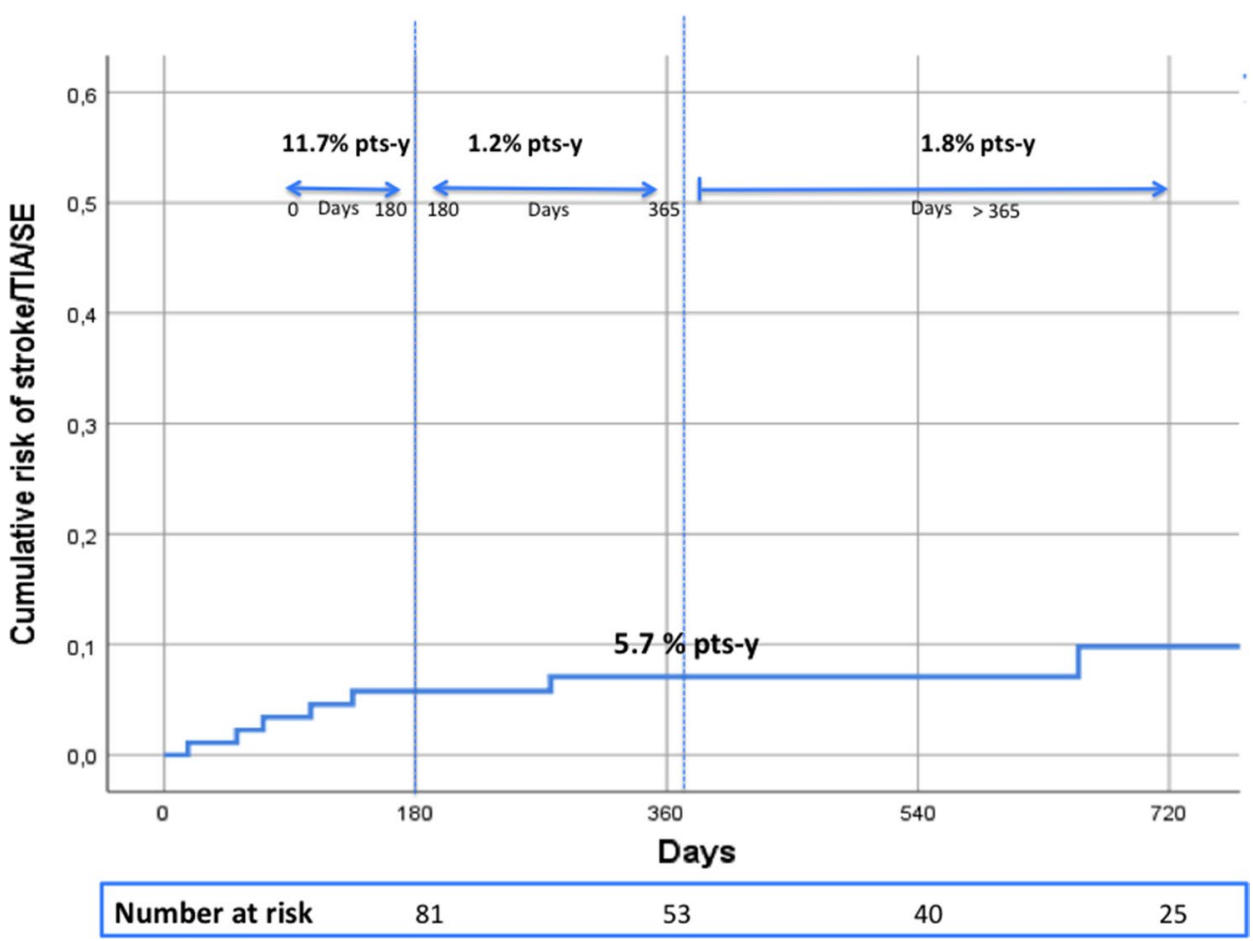


Table 3 Main characteristics of the study patients with thromboembolic events

\begin{tabular}{|c|c|c|c|c|c|c|c|c|c|}
\hline Pt. ID & $\begin{array}{l}\text { Age, } \\
\text { years }\end{array}$ & Sex & $\begin{array}{l}\mathrm{CHA}_{2} \mathrm{DS}_{2-} \\
\text { VASc score }\end{array}$ & Previous stroke & Type of DOAC & Type of AED & Type of event & Fatal event & $\begin{array}{l}\text { Time to } \\
\text { event } \\
\text { (days) }\end{array}$ \\
\hline 1 & 75 & $\mathrm{~F}$ & 4 & No & Rivaroxaban $20 \mathrm{mg}$ & $\begin{array}{l}\text { Carbamazepine } \\
400 \mathrm{mg} \text { bid }\end{array}$ & Ischaemic stroke & No & 786 \\
\hline 2 & 75 & $\mathrm{~F}$ & 6 & Yes & $\begin{array}{l}\text { Apixaban } \\
5 \mathrm{mg} \text { bid }\end{array}$ & $\begin{array}{l}\text { Valproic acid } \\
500 \mathrm{mg}\end{array}$ & TIA & No & 105 \\
\hline 3 & 77 & $\mathrm{~F}$ & 5 & Yes & $\begin{array}{l}\text { Apixaban } \\
5 \mathrm{mg} \text { bid }\end{array}$ & $\begin{array}{l}\text { Levetiracetam } \\
250 \mathrm{mg} \text { bid }\end{array}$ & Ischaemic stroke & No & 17 \\
\hline 4 & 81 & M & 5 & Yes & $\begin{array}{l}\text { Apixaban } \\
5 \mathrm{mg} \text { bid }\end{array}$ & $\begin{array}{l}\text { Levetiracetam } \\
500 \text { bid }\end{array}$ & Ischaemic stroke & No & 52 \\
\hline 5 & 87 & $\mathrm{~F}$ & 7 & Yes & $\begin{array}{l}\text { Apixaban } \\
2.5 \mathrm{mg} \text { bid }\end{array}$ & $\begin{array}{l}\text { Carbamazepine } \\
400 \mathrm{mg} \text { bid }\end{array}$ & Ischaemic stroke & No & 947 \\
\hline 6 & 90 & M & 2 & No & Rivaroxaban $15 \mathrm{mg}$ & $\begin{array}{l}\text { Levetiracetam } \\
500 \mathrm{mg} \text { bid }\end{array}$ & Ischaemic stroke & No & 277 \\
\hline 7 & 82 & M & 3 & No & Dabigatran $110 \mathrm{mg}$ bid & $\begin{array}{l}\text { Levetiracetam } \\
250 \mathrm{mg} \text { bid }\end{array}$ & Ischaemic stroke & Yes & 655 \\
\hline 8 & 88 & $\mathrm{~F}$ & 8 & Yes & Rivaroxaban $15 \mathrm{mg}$ & $\begin{array}{l}\text { Fenobarbital } \\
100 \mathrm{mg}+\text { leveti- } \\
\text { racetam } \\
250 \mathrm{mg} \mathrm{bid}\end{array}$ & Ischaemic stroke & Yes & 135 \\
\hline 9 & 93 & $\mathrm{~F}$ & 7 & Yes & Rivaroxaban $15 \mathrm{mg}$ & Fenobarbital $100 \mathrm{mg}$ & Ischaemic stroke & Yes & 71 \\
\hline
\end{tabular}

$A E D$ anti-epileptic drug, $D O A C$ direct oral anticoagulant, $F$ female, $M$ male, $T I A$ transient ischaemic attack, bid twice daily

Fig. 2 Risk and incidence rates of major bleeding. pts-y patientyear

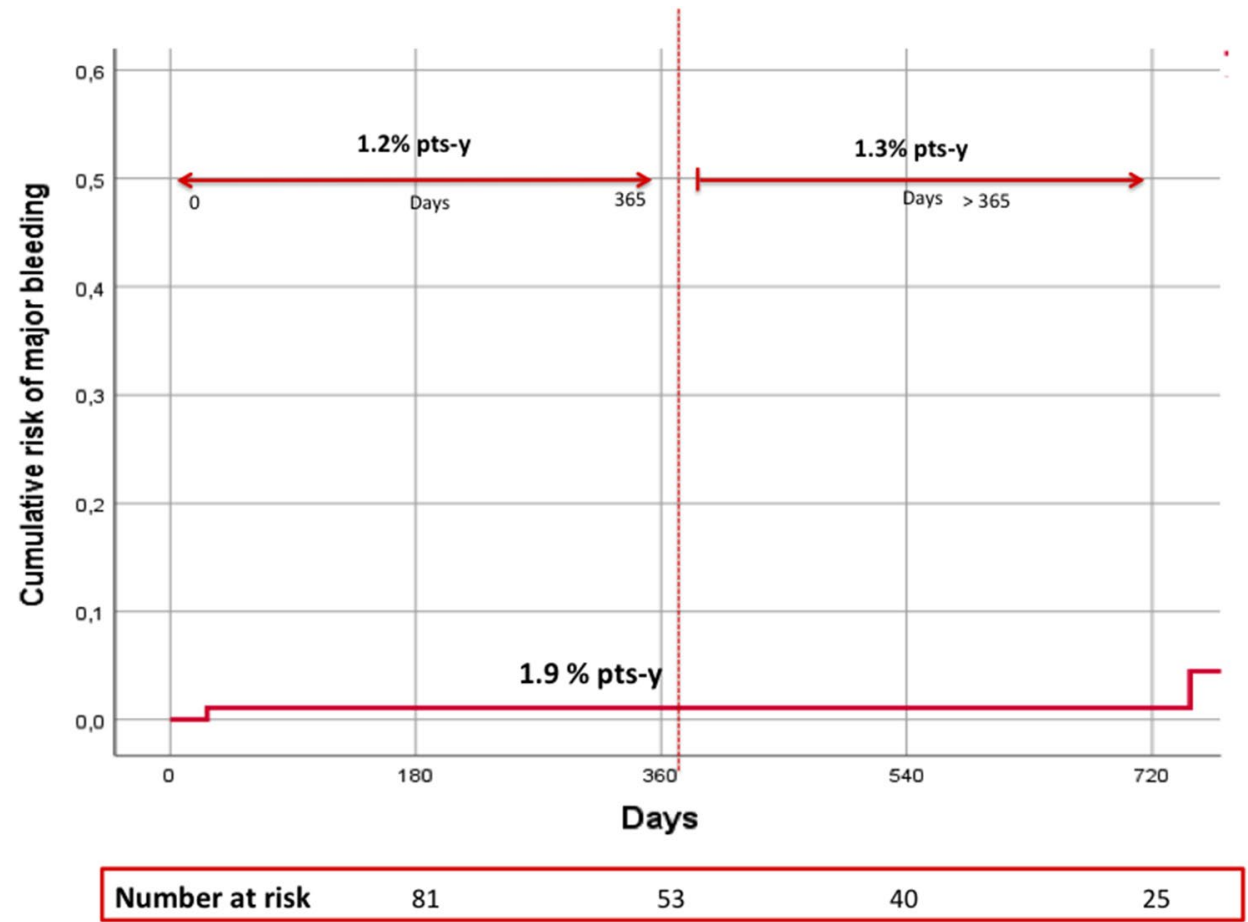

Administration (FDA) Adverse Event Reporting System, the risk of ischaemic and thromboembolic events in patients concomitantly treated with factor Xa-inhibitors, mainly apixaban and rivaroxaban, and enzyme-inducing AEDs, was higher than in those treated with other antiepileptic drugs
[29]. In addition, in a retrospective study, DOAC concentrations were lower than expected in patients treated with carbamazepine, phenobarbital and phenytoin $(50 \%$ of patients below the 5th percentile) [30]. In our study, we included a wide range of AEDs and found that patients concomitantly 
treated with DOACs and AEDs appear to have a relatively high rate of thromboembolic events. However, the study was not powered to detect potential differences between DOACs or AEDs. Indeed, whether this increased risk of ischaemic events is related to the enzyme inducing effect of some of these medications, or to the underlying clinical features such as history of stroke or pathological characteristics of these patients is unclear.

However, the number of patients treated with known enzyme-inducer AEDs was substantially lower than the number of patients treated with antiepileptics that are not considered enzyme inducers. In our study, the risk of ischaemic stroke/TIA/SE between these two groups of patients did not differ. This may in part be related to the limited number of outcome events occurring during the study period. However, we believe that a more cautious approach by physicians should be considered when prescribing carbamazepine, phenobarbital or phenytoin to patients on DOACs.

In our study, we found an incidence of major bleeding of $1.9 \%$ patient/year, lower than that reported in a recent retrospective study on Asian insurance claims data. A higher risk of major bleeding was observed in patients on DOACs and valproic acid (15.3\% patient-year), phenytoin (13.5 patientyear) and levetiracetam (13.2\% patient-year) compared to patients on DOACs alone [31]. However, data on bleedingrelated potential covariate such as dosage of DOAC, liver and renal function as well as thromboembolic events were not reported in this study.

Finally, this study has some limitations. The limited number of patients included, the absence of a comparison group, the pooling of a wide range of anticoagulants and AEDs, each with distinct pharmacokinetic properties, and the lack of dosage of AEDs and that of DOACs or AEDs plasma concentration may limit the value of our results. However, the prospective data collection and the duration of the study follow-up are strengths of our study.

\section{Conclusions}

In conclusion, we observed that patients concomitantly treated with DOACs and AEDs appear to have a relatively high rate of thromboembolic events. Indeed, the interaction between AEDs and DOACs might be of high clinical relevance, leading to a potential increase in morbidity and mortality. Caution should be applied when considering anticoagulation treatment in AF patients treated with AEDs.

\section{Declarations}

Funding Open access funding provided by Università degli Studi di Perugia within the CRUI-CARE Agreement.
Conflict of interest Michela Giustozzi, Matteo Mazzetti and Maria Cristina Vedovati have no conflict of interest to declare. Maurizio Paciaroni received honoraria as a member of the speaker bureau of Aspen, Sanofi-Aventis, Boehringer Ingelheim, Bayer, Bristol Meyer Squibb, Daiiki Sankyo and Pfizer. Giancarlo Agnelli received honoraria as a member of the speaker bureau of Bristol-Meyers-Squibb, Pfizer and Bayer. Cecilia Becattini received honoraria as a member of the speaker bureau of Bristol-Meyers-Squibb, Pfizer, Bayer and Boehringer Ingelheim.

Ethics approval All procedures in this study were in accordance with the 1964 Helsinki declaration and its amendments. The study was approved by the local institutional review board.

Informed consent Written informed consent was obtained from patients, parents or caregivers.

Availability of data and material Data that support the findings of this study are available from the corresponding author upon reasonable request.

Code availability Not applicable.

Consent to participate Informed consent was obtained from all individual participants included in the study.

Consent for publication Not applicable.

Authors' contributions Michela Giustozzi contributed to the interpretation of data, drafting and critical revision of the manuscript and is the guarantor of the paper, taking responsibility for the integrity of the work as a whole, from inception to published article; Matteo Mazzetti, Maurizio Paciaroni, Giancarlo Agnelli, Cecilia Becattini and Maria Cristina Vedovati contributed to the conception and design of the study, to the statistical analyses, to the interpretation of data, drafting and critical revision of the manuscript.

Open Access This article is licensed under a Creative Commons Attribution-NonCommercial 4.0 International License, which permits any non-commercial use, sharing, adaptation, distribution and reproduction in any medium or format, as long as you give appropriate credit to the original author(s) and the source, provide a link to the Creative Commons licence, and indicate if changes were made. The images or other third party material in this article are included in the article's Creative Commons licence, unless indicated otherwise in a credit line to the material. If material is not included in the article's Creative Commons licence and your intended use is not permitted by statutory regulation or exceeds the permitted use, you will need to obtain permission directly from the copyright holder. To view a copy of this licence, visit http://creativecommons.org/licenses/by-nc/4.0/.

\section{References}

1. Ruff CT, Giugliano RP, Braunwald E, Hoffman EB, Deenadayalu N, Ezekowitz MD, Camm AJ, Weitz JI, Lewis BS, Parkhomenko A, Yamashita T, Antman EM. Comparison of the efficacy and safety of new oral anticoagulants with warfarin in patients with atrial fibrillation: a meta-analysis of randomised trials. Lancet. 2014;383(9921):955-62. https://doi.org/10.1016/S0140 -6736(13)62343-0.

2. van Es N, Coppens M, Schulman S, Middeldorp S, Büller HR. Direct oral anticoagulants compared with vitamin $\mathrm{K}$ antagonists 
for acute venous thromboembolism: evidence from phase 3 trials. Blood. 2014;124(12):1968-75. https://doi.org/10.1182/blood -2014-04-571232.

3. Camm AJ, Kirchhof P, Lip GY, Schotten U, Savelieva I, Ernst S, Van Gelder IC, Al-Attar N, Hindricks G, Prendergast B, Heidbuchel H, Alfieri O, Angelini A, Atar D, Colonna P, De Caterina R, De Sutter J, Goette A, Gorenek B, Heldal M, Hohloser SH, Kolh P, Le Heuzey JY, Ponikowski P, Rutten FH, Vahanian A, Auricchio A, Bax J, Ceconi C, Dean V, Filippatos G, Funck-Brentano C, Hobbs R, Kearney P, McDonagh T, Popescu BA, Reiner Z, Sechtem U, Sirnes PA, Tendera M, Vardas PE, Widimsky P, Agladze V, Aliot E, Balabanski T, Blomstrom-Lundqvist C, Capucci A, Crijns H, Dahlof B, Folliguet T, Glikson M, Goethals M, Gulba DC, Ho SY, Klautz RJ, Kose S, McMurray J, Perrone Filardi P, Raatikainen P, Salvador MJ, Schalij MJ, Shpektor A, Sousa J, Stepinska J, Uuetoa H, Zamorano JL, Zupan I. Guidelines for the management of atrial fibrillation: the Task Force for the Management of Atrial Fibrillation of the European Society of Cardiology (ESC). Europace. 2010;12:1360-420.

4. Galgani A, Palleria C, Iannone LF, De Sarro G, Giorgi FS, Maschio M, Russo E. Pharmacokinetic interactions of clinical interest between direct oral anticoagulants and antiepileptic drugs. Front Neurol. 2018;9:1067.

5. Hiemke C, Bergemann N, Clement HW, Conca A, Deckert J, Domschke K, Eckermann G, Egberts K, Gerlach M, Greiner C, Gründer G, Haen E, Havemann-Reinecke U, Hefner G, Helmer R, Janssen G, Jaquenoud E, Laux G, Messer T, Mössner R, Müller MJ, Paulzen M, Pfuhlmann B, Riederer P, Saria A, Schoppek B, Schoretsanitis G, Schwarz M, Gracia MS, Stegmann B, Steimer W, Stingl JC, Uhr M, Ulrich S, Unterecker S, Waschgler R, Zernig G, Zurek G, Baumann P. Consensus guidelines for therapeutic drug monitoring in neuropsychopharmacology: update 2017. Pharmacopsychiatry. 2018;51(1-02):9-62.

6. Patsalos PN, Perucca E. Clinically important drug interactions in epilepsy: interactions between antiepileptic drugs and other drugs. Lancet Neurol. 2003;2(8):473-81.

7. Cytochrome P-450 CYP3A4 Inducers. DrugBank. https://www. drugbank.ca/categories/DBCAT003896. Accessed 10 Oct 2015.

8. P-glycoprotein inducers. DrugBank. https://www.drugbank.ca/ categories/DBCAT002666. Accessed 6 Sep 2020.

9. Hsu CY, Chen TH, Su YW, Chang CC, Chen MH, Leu HB, Huang $\mathrm{PH}$, Chen JW, Lin SJ. Usefulness of the CHADS2 score for determining risk of seizure in patients with atrial fibrillation. Am J Cardiol. 2016;118(9):1340-4. https://doi.org/10.1016/j.amjca rd.2016.07.063.

10. Galovic M, Döhler N, Erdélyi-Canavese B, Felbecker A, Siebel P, Conrad J, Evers S, Winklehner M, von Oertzen TJ, Haring HP, Serafini A, Gregoraci G, Valente M, Janes F, Gigli GL, Keezer MR, Duncan JS, Sander JW, Koepp MJ, Tettenborn B. Prediction of late seizures after ischaemic stroke with a novel prognostic model (the SeLECT score): a multivariable prediction model development and validation study. Lancet Neurol. 2018;17(2):143-52.

11. Steffel J, Verhamme P, Potpara TS, Albaladejo P, Antz M, Desteghe L, Haeusler KG, Oldgren J, Reinecke H, Roldan-Schilling V, Rowell N, Sinnaeve P, Collins R, Camm AJ, Heidbüchel H; ESC Scientific Document Group. The 2018 European Heart Rhythm Association Practical Guide on the use of non-vitamin K antagonist oral anticoagulants in patients with atrial fibrillation. Eur Heart J. 2018;39(16):1330-1393.

12. Giustozzi M, Vedovati MC, Verdecchia P, Pierpaoli L, Verso M, Conti S, Cianella F, Marchesini E, Filippucci E, Agnelli G, Becattini C. Vitamin $\mathrm{K}$ and non-vitamin $\mathrm{K}$ antagonist oral anticoagulants for non-valvular atrial fibrillation in real-life. Eur J Intern Med. 2016;33:42-6.
13. Lip GY, Nieuwlaat R, Pisters R, Lane DA, Crijms HJ. Refining clinical risk stratification for predicting stroke and thromboembolism in atrial fibrillation using a novel risk factor-based approach: the Euro Heart Survey on Atrial Fibrillation. Chest. 2010;137:263-72.

14. Pisters R, Lane DA, Nieuwlaat R, de Vos CB, Crijns HJ, Lip GY. A novel user-friendly score (HAS-BLED) to assess 1-year risk of major bleeding in patients with atrial fibrillation: the Euro Heart Survey. Chest. 2010;138:1093-100.

15. Schulman S, Kearon C. Definition of major bleeding in clinical investigations of antihemostatic medicinal products in non-surgical patients. J Thromb Haemost. 2005;3:692-4.

16. Giessmann T, May K, Modess C, Wegner D, Hecker U, Zschiesche M, Dazert P, Grube M, Schroeder E, Warzok R, Cascorbi I, Kroemer HK, Siegmund W. Carbamazepine regulates intestinal P-glycoprotein and multidrug resistance protein MRP2 and influences disposition of talinolol in humans. Clin Pharmacol Ther. 2004;76(3):192-200.

17. Andreasen AH, Brøsen K, Damkier P. A comparative pharmacokinetic study in healthy volunteers of the effect of carbamazepine and oxcarbazepine on cyp3a4. Epilepsia. 2007;48(3):490-6.

18. Puranik YG, Birnbaum AK, Marino SE, Ahmed G, Cloyd JC, Remmel RP, Leppik IE, Lamba JK. Association of carbamazepine major metabolism and transport pathway gene polymorphisms and pharmacokinetics in patients with epilepsy. Pharmacogenomics. 2013;14(1):35-45.

19. Jing X, Liu X, Wen T, Xie S, Yao D, Liu X, Wang G, Xie L. Combined effects of epileptic seizure and phenobarbital induced overexpression of P-glycoprotein in brain of chemically kindled rats. Br J Pharmacol. 2010;159(7):1511-22.

20. Moerman L, Wyffels L, Slaets D, Raedt R, Boon P, De Vos F. Antiepileptic drugs modulate P-glycoproteins in the brain: a mice study with (11)C-desmethylloperamide. Epilepsy Res. 2011;94(1-2):18-25.

21. Nicolas JM, Collart P, Gerin B, Mather G, Trager W, Levy R, Roba J. In vitro evaluation of potential drug interactions with levetiracetam, a new antiepileptic agent. Drug Metab Dispos. 1999;27(2):250-4.

22. Cerveny L, Svecova L, Anzenbacherova E, Vrzal R, Staud F, Dvorak Z, Ulrichova J, Anzenbacher P, Pavek P. Valproic acid induces CYP3A4 and MDR1 gene expression by activation of constitutive androstane receptor and pregnane $\mathrm{X}$ receptor pathways. Drug Metab Dispos. 2007;35(7):1032-41.

23. Wen X, Wang JS, Kivistö KT, Neuvonen PJ, Backman JT. In vitro evaluation of valproic acid as an inhibitor of human cytochrome P450 isoforms: preferential inhibition of cytochrome P450 2C9 (CYP2C9). Br J Clin Pharmacol. 2001;52(5):547-53.

24. Huisman MV, Rothman KJ, Paquette M, Teutsch C, Diener HC, Dubner SJ, Halperin JL, Ma CS, Zint K, Elsaesser A, Lu S, Bartels DB, Lip GYH; GLORIA-AF Investigators. Two-year followup of patients treated with dabigatran for stroke prevention in atrial fibrillation: Global Registry on Long-Term Antithrombotic Treatment in Patients with Atrial Fibrillation (GLORIA-AF) registry. Am Heart J. 2018;198:55-63.

25. O'Brien EC, Kim S, Thomas L, Fonarow GC, Kowey PR, Mahaffey KW, Gersh BJ, Piccini JP, Peterson ED. Clinical characteristics, oral anticoagulation patterns, and outcomes of medicaid patients with atrial fibrillation: insights from the outcomes registry for better informed treatment of atrial fibrillation (ORBIT-AF I) registry. J Am Heart Assoc. 2016;5(5):e002721.

26. Bassand JP, Virdone S, Goldhaber SZ, Camm AJ, Fitzmaurice DA, Fox KAA, Goto S, Haas S, Hacke W, Kayani G, Mantovani LG, Misselwitz F, Pieper KS, Turpie AGG, van Eickels M, Verheugt FWA, Kakkar AK. Early risks of death, stroke/systemic embolism, and major bleeding in patients with newly diagnosed atrial fibrillation. Circulation. 2019;139(6):787-98. 
27. Mathy FX, Dohin E, Bonfitto F, Pelgrims B. Drug-drug interaction between levetiracetam and non-vitamin K antagonist anticoagulants. Eur Heart J. 2019;40(19):1571.

28. Paciullo F, Costa C, Gresele P. Rivaroxaban plasma levels and levetiracetam: a case report. Ann Intern Med. 2020;173(1):71-2.

29. Perlman A, Wanounou M, Goldstein R, Choshen Cohen L, Singer DE, Muszkat M. Ischemic and thrombotic events associated with concomitant Xa-inhibiting direct oral anticoagulants and antiepileptic drugs: analysis of the FDA adverse event reporting system (FAERS). CNS Drugs. 2019;33(12):1223-8.

30. Perlman A, Hochberg-Klein S, Choshen Cohen L, Dagan G, Hirsh-Raccah B, Horwitz E, Aldouby-Bier G, Negev T, Matok I,
Azoulay L, Kalish Y, Muszkat M. Management strategies of the interaction between direct oral anticoagulant and drug-metabolizing enzyme inducers. J Thromb Thrombol. 2019;47(4):590-5.

31. Wang CL, Wu VC, Chang KH, Tu HT, Kuo CF, Huang YT, Chu $\mathrm{PH}$, Kuo CC, Chang SH. Assessing major bleeding risk in atrial fibrillation patients concurrently taking non-vitamin $\mathrm{k}$ antagonist oral anticoagulants and antiepileptic drugs. Eur Heart J Cardiovasc Pharmacother. 2019. https://doi.org/10.1093/ehjcvp/pvz035. 